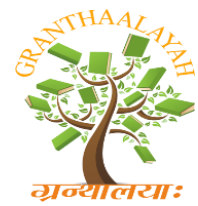

INTERNATIONAL JOURNAL OF RESEARCH GRANTHAALAYAH

A knowledge Repository

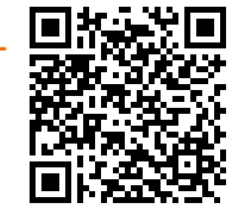

Management

\title{
ROLE OF REFERRAL MARKETING IN HIGHER EDUCATION WITH SPECIAL REFERENCE TO PRIVATE SECTOR
}

\author{
Pallavi Gupta *1 \\ ${ }^{* 1}$ Assistant Professor, (Qualified UGC-NET DEC-2012) Department of Business \\ Administration, Bhabha Institute of Technology Kanpur, U.P., INDIA
}

\begin{abstract}
Referral marketing is being increasingly used in marketing of services, like education, finance \& other hospitality services. As more and more private universities have come into existence. So all are trying to woo students to pursue variety of technical and non-technical courses offered by them, \& referral marketing may be an Innovative tool in their marketing efforts. Referral marketing is using People as the new media for reaching prospective customers. In the context of Higher education in general the competition in private sector between institutions, is intensifying. In Education, students are seen as the customers. Some authors view the corporate as the customers of institutions and students as products. Education being a service and is people based, referral marketing is suitable \& Offering incentives to encourage referral behavior is being practiced.

This study basically focuses on revealing how colleges and institutions are using promotional tools to position their distinctiveness and what is the importance of Referral marketing in it. This study aims at to gauge the effectiveness of WOM. Ultimately how does incentive influence the referral behavior?.
\end{abstract}

Keywords:

Referral Marketing, WOM, Higher education, Incentive.

Cite This Article: Pallavi Gupta, "ROLE OF REFERRAL MARKETING IN HIGHER EDUCATION WITH SPECIAL REFERENCE TO PRIVATE SECTOR” International Journal of Research - Granthaalayah, Vol. 4, No. 5 (2016): 65-72.

\section{INTRODUCTION}

India's higher education system is the third largest in the world, next to the United States and China. The Higher education in India has different and divergent streams each of which is monitored by an apex body. These apex bodies are indirectly controlled by the Ministry of Human Resource Development and are funded by the state governments.

The main governing body at the tertiary level is the University Grants Commission, which enforces its standards, advises the government, and helps coordinate between the centre and the 
state. Accreditation for higher learning is overseen by 12 autonomous institutions established by the University Grants Commission. Indian higher education system has expanded at a fast pace by adding nearly 20,000 colleges and more than 8 million students in a decade from 2000-01 to 2010-11. As of 15.01.2016, India has 46 central universities, 342 state universities, 125 deemed to be universities, and 228 private universities, total 741 universities are there.

\begin{tabular}{|l|l|l|l|l|l|}
\hline Year & $\begin{array}{l}\text { Central } \\
\text { universities }\end{array}$ & $\begin{array}{l}\text { State } \\
\text { universities }\end{array}$ & $\begin{array}{l}\text { Deemed to be } \\
\text { universities }\end{array}$ & $\begin{array}{l}\text { Private } \\
\text { Universities }\end{array}$ & Total \\
\hline $1950-51$ & 3 & 24 & - & - & 27 \\
\hline $1970-71$ & 5 & 79 & 9 & - & 93 \\
\hline $1990-91$ & 10 & 137 & 29 & - & 176 \\
\hline $2005-06$ & 18 & 205 & 95 & 7 & 325 \\
\hline $2012-13$ & 43 & 308 & 103 & 201 & 655 \\
\hline $2015-16$ & 46 & 342 & 125 & 228 & 741 \\
\hline
\end{tabular}

From most categorized point of view, in Uttar Pradesh, approximately 59 Universities are there in toto, including Private, Deemed to be, State and Central universities which are imparting technical or non technical education. Out of which approximately 24 universities are Private which are providing professional degrees such as:

B.Tech

M.Tech

B.B.A

M.B.A

B.C.A

M.C.A etc.

In such a cut throat competition, where private education industry is only focused towards monetary benefits by providing degrees without quality. Referral marketing has emerged as an innovative approach. Possession of a professional degree is considered to be a Golden tool to get into a reputed MNC. But there is great depression and dissatisfaction among students and their families on account of shattered dreams. This causes great challenge for survival of private colleges and institutions involved in providing professional degrees sans knowledge.

Referral marketing is an innovative method of promoting their services to prospects through referrals, usually word of mouth. Such referrals often happen spontaneously but businesses can influence this through appropriate strategies. Referral marketing is a process to increase word of mouth marketing by encouraging customers and contacts to talk as much as possible about a brand or service, including online.

Simply put, referral marketing is spreading the word about a product or service through a business' existing customers, rather than traditional advertising. Word-of-mouth marketing, which occurs when others tell each other about a business, is also considered a form of referral marketing.

According to the New York Times, $65 \%$ of all new business comes from referrals. That means on average, two-thirds of consumers make purchases because someone they know recommended a particular product or service. 
Recent findings from Nielsen support the remarkable potential of referral marketing, observing that people are four times more likely to buy when referred by a friend. Strategic use of referral marketing allows professionals to tap into the power of other's recommendations to achieve exceptional results especially in higher education industry.

Because in education sector services are intangible \& satisfaction is dependant on variety of factors such as quality of education, atmosphere of study, standard of teachers \& their methods of teaching, modern infrastructure \& placements. And in case of shattered dreams about such intangibles there is the great deal of dissatisfaction among students \& their families. This has raised the question of survival for few private colleges; indulge in just commercializiling education services.

Recent Surveys reveals the facts that more than half of Indian students do not possess the skills required for employment even as they are educated; Teachers said that $57 \%$ of students in the country are educated but not adequately prepared for employment. The survey also said that 75 $\%$ teachers have called for restructuring of course curriculum in collaboration with industry.

'The Pearson Voice of Teacher Survey' also found that teachers in Delhi do not think that the education system in the country is providing holistic education to students "Only $46 \%$ of teachers in the capital feel that education system is providing holistic education," it said.. According to the survey over $66 \%$ teachers recommend provision of computer and internet connectivity across institutions and $62 \%$ said that installation of smart boards is a key requirement for integration of ICT in the education system.

Such surveys have raised a big question mark on the quality \& standard of education provided by such educational private institutions. On one hand, it has caused problem of survival of such institutions. On the other hand, it has presented an opportunity to prove their distinctiveness in terms of quality. Consequently Referral marketing has emerged as an innovative tool of marketing to woo students.

\section{OBJECTIVES}

- To know the challenges faced by private universities \& colleges at present.

- To gauge the effectiveness of WOM/ Referral Marketing.

- To measure the reliability of Referral marketing.

- To identify other factors influencing positive WOM.

- To understand the methods of creating positive WOM.

\section{CHALlENGES FOR PRIVATE PLAYERS IN HIGHER EDUCATION INDUSTRY}

The broad issues to be addressed include quality, equity, affordability, inclusiveness, funding and regulation, which require a cohesive and integrated approach for solutions. 
Poor Employability: Poor employability is the main problem of private educational institutions. Poor industry academia linkages, neglect of soft skills, inability to solve real time problems, mismatch of curriculum and industry needs lead to poor employability of graduates.

Lack of uniformity in various courses: It is another one of the major problems of institutions that the courses being offered by educational institutions. There is no uniformity in the content, pedagogy, and forms of assessments by different private institutions.

Poor Regulation: The councils which are responsible for assuring the quality education for students are not playing their roles effectively. Only 161 universities and 4,371 colleges were accredited by The National Assessment and Accreditation Council (NAAC) as on March 2011.

Outdated Curricula: The curriculum followed in most of the institutes is not able to keep pace with the fast changing economic and socio-technical environment. Main challenge for MNCs for placing the technical \& professional student is the gap which they find between their knowledge $\&$ sense of applicability.

Shortage of Faculty: Institutes of higher education are facing acute shortage of good quality faculty. The high ranking students prefer to join the industry due to better career prospects.

On one hand, the restrictions on the academic qualifications sometimes create the challenges in hiring good quality professionals from the industry while on the other hand, fresher's which join the education industry without having experience of corporate are not well versed with practicality of technical knowledge. Consequently their production is poor \& every year quality of pass out students is getting degraded.

Saturation: In absence of placement of students, expectations of students \& their parents have scattered. Consequently there has come the point of saturation in terms of growth \& admission in technical \& professional courses like B.Tech, MBA, and MCA etc.

There are major challenges such as: High time lag in introduction of reforms due to various reasons. Deterioration in quality of education especially in private sector due to lack of availability of trained faculty over regulation - Control over course curriculum, entrance tests, fees, etc. In Uttar Pradesh alone, out of the 24 private universities in the state, politicians have an active stake in the management of seven universities. Another seven universities have businessmen holding key positions. Thirteen of the private universities do not have any accreditation till date. Apart from the aforesaid example there are several allegations against private colleges and deemed universities. This is despite the fact that India needs private investment to meet the requirement in Higher education sector.

And in such a time of saturation the remaining players are updating \& continuously upgrading their standards in terms of diversification of courses, Quality, Training \& Placement activities. So that they can use this USP for their Word of Mouth Promotion. This is considered to be the most reliable tool of promotion of services. That's why the existing private players are using referral marketing to encase their current investment. 


\section{IMPORTANCE OF REFERRAL MARKETING IN HIGHRER EDUCATION PRIVATE SECTOR}

In a service-led industry, such as higher education, customer referrals have a very important role to play in enhancing the reputation and value added aspects of the brand. Therefore, with this in mind, it is important for private institutions to encourage positive feedback from students and staff alike .Of course, provision of a quality service that adds value to the end user, all delivered with a good dose of customer care. Failure to do this will ultimately result in poor customer (student) satisfaction. In marketing circles, this is often referred to as referral marketing or word of mouth. It's a cost effective means to promoting course to new group of prospects.

\section{THE IMPORTANCE OF REFERRALS}

What are the benefits of adopting students as brand advocates for the university? Here are top reasons for engaging students in the marketing.

\section{Student Experience}

Student experience is the natural thing which is the foundation of positive or negative WOM for any college of institutions. Student is considered as the product of an institutions if his/her own experience in terms of quality studies, training, internships, live projects training, visits, seminars $\&$ placements is positive. So nothing will be stronger way to create referrals for the college.

\section{Trustworthy Source}

Remember, students are also customers and student prospects are likely to look at those students as a credible source of information. Before taking admission in any college what people do is to ask his/her relative about best colleges, their facilities etc \& the opinion is ultimately realized by the prospects are given the stakeholders (Students, Staff, Alumni) of the college only.

\section{Risk Elimination}

People don't like risk and this is particularly true when a big investment is being made. Referring particular queries to a current student can be a means for gaining an implied endorsement. Of course, risk can not be completely eliminated, but a customer referral will help.

\section{Cost Effective}

Word of mouth is often referred to as the best form of marketing, simply because of its credibility and its cost effectiveness. In a higher education environment such as ours, more often than not, students live and breathe the university experience, meaning it can be very easy indeed to find students that want to actively promote their university to their peers.

\section{CONCLUSION}

This is a need to rethink on present system of higher education provided by private sector. They should realize the fact that education is intangible service which can neither be commercialized completely nor can be converted into just profit earning organization. 
Although process of providing education is $100 \%$ professional but its $1000 \%$ personal. In today's competitive world when everything is sold in market just for the sake of money few things in fact few services should keep aloof from this motive. Education industry is one of them. It is the field which is responsible for pre training of students before their actual launching in market. So there is need to identify some following factors which are responsible for positive word of mouth promotion of private players.

- It is observed that fees charged by the Private universities \& colleges are very high when compare to the central and state government universities \& colleges. In order to create positive WOM colleges should try to either increase their standard of education or should try to provide quality education with least cost.

- For enhancing the student's experience there is need to consider possibilities of allowing experience professionals from industry to be hired instead of hiring only $\mathrm{PhD}$ 's for leadership positions in academics.

- The number of private universities is increasing rapidly. In order to avoid an unhealthy completion within the private universities within the state, there should be mechanism of common entrance examination exclusively for the private universities. The common entrance should be in the form of a test and counseling and the students will be admitted depending upon their admission ranking.

- For creating students experience matchless private universities should maintain the quality of teaching, they should appoint the faculty as per the UGC regulations and the pay scales should be paid at par with the regulations.

- In order to create positive image $\&$ to avoid the commercialization of education, all the private universities or colleges should try to be more transparent in terms of admission, fee collection, distribution of scholarships and training, placements services.

If these all conditions are fulfilled successfully by the private universities \& colleges, responsible for providing professional \& technical degrees, would automatically be benefitted by having positive WOM or referrals for their services \& there is no doubt that referrals are the most reliable method of promotion. This is free of cost \& can be used strategically for enhancing its effect in market.

\section{SUGGESTIONS}

The higher education sector is now more competitive than ever before and with the rise of competition it is essential for private colleges \& universities to provide and demonstrate a student experience \& profiles with added value.

If any private college/university seriously work on it, so it will not only will help with conversion of enquiries to enrolments but it will also aid prospects with making a choice that is right for them and consequently ensure a high level of retention.

In general, there are various on line \& offline methods of creating referrals or of WOM promotions. Few modern methods are given below. Specifically, which are low in cost but most effective in use \& result. 


\section{METHODS FOR INCREASING REFERRALS}

BLOGS: A culture now exists where it is common practice to write, read, film and share blogs about interests and experiences. And, if students are blogging, it's more than likely they're talking about us, making reference to their experiences at University. Some universities have already begun to recognize this and are now posting student blogs on their corporate websites.

With a bit of forethought, this is something that could also be implemented within the web pages of any faculty or department. And, if done well, this would help give prospective students a real and credible taste of the University experience.

There are, of course, a vast number of student blogs online, but here are a couple examples of blogs, picked out at random, where the university has used them to showcase their student experience.

SOCIAL MEDIA: Now a days use of social media is very common practice for all type of people in our society. On one hand, it provides the facility of being connected. On the other hand, it also provides service for sharing or expressing the views, thoughts \& experiences with all loved ones. It has given a public platform to share with the world exactly how does one feel at any particular moment in time. Private universities \& College can use this platform strategically for their WOM promotions.

VIDEOS: For creating a strong brand identity it is important to be narrative in approach. And videos of student's experience at college, classes, games, extra-curricular activities, trainings \& of other academic activities can not only grab the attention of prospects but also can give them chance to be emotionally connected with the atmosphere of college. This will ultimately help in creating a sense of identity.

\section{REFERENCES}

[1] S. Jeelani and M.V. Ramana Murthy \& S.Harisingh Naik. Volume 3, Issue 5, SeptemberOctober 2014 ISSN 2278-6856 Private Universities : Challenges and opportunities in Higher Education

[2] D. Malmarugan, Dr. H. Sankaran. 8-10 April, 2007, International Marketing Conference on Marketing \& Society, IIMK Referral Marketing in Management Education- An Assessment

[3] EDUCATION Devanathan Malmarugan, Hari Sankaran. Innovative Marketing, Volume 3, Issue 2, 2007 REFERRAL MARKETING - AN INNOVATIVE APPROACH IN MANAGEMENT

[4] NUEPA and the British Council of India on 10-11 November 2014 in New Delhi Seminar on Massification of higher education in large system countries, jointly organized by the Centre for Policy Research in Higher Education (CPRHE).

[5] https://en.wikipedia.org/wiki/Higher_education_in_India

[6] https://en.wikipedia.org/wiki/Indian_Institutes_of_Technology

[7] http://education.newkerala.com/india-education/india-education.html 
[8] http://www.ugc.ac.in/oldpdf/Consolidated\%20list\%20of\%20Central\%20Universities\%20 as\%20on\%2015.01.2016.pdf

[9] http://www.ugc.ac.in/oldpdf/State\%20University/Consolidated\%20List\%20of\%20State\% 20Universities\%20as\%20on\%2015.01.2016.pdf

[10] http://www.ugc.ac.in/oldpdf/Deemed\%20University/Consolidated\%20List\%20of\%20Dee med\%20Universities\%20as\%20on\%2015.01.2016.pdf

[11] http://www.ugc.ac.in/oldpdf/Private\%20University/Consolidated\%20List\%20Private\%20 Universities\%20as\%20on\%2014.01.2016.pdf

[12] http://www.ugc.ac.in/privateuniversitylist.aspx?id=33\&Unitype=3

[13] http://www.marketing-schools.org/types-of-marketing/referral-marketing.html

[14] https://en.wikipedia.org/wiki/Referral_marketing

[15] http://yourstory.com/2015/09/indian-students-not-prepared-employment/

[16] http://www.cppr.in/innews/private-investment-in-higher-education-challenges-andscepticism-governance-now/

[17] http://chestermarketing.blogspot.in/2013/12/engaging-university-brand-advocates.html

[18] http://www.forbes.com/2010/07/21/viral-marketing-referral-program-entrepreneurssales-marketing-wharton.html 